This item was submitted to Loughborough's Research Repository by the author.

Items in Figshare are protected by copyright, with all rights reserved, unless otherwise indicated.

\title{
Transformative technologies for safely managed sanitation
}

\section{PLEASE CITE THE PUBLISHED VERSION}

http://dx.doi.org/10.1680/jmuen.16.00026

\section{PUBLISHER}

(C) ICE Publishing

\section{VERSION}

AM (Accepted Manuscript)

\section{PUBLISHER STATEMENT}

This work is made available according to the conditions of the Creative Commons Attribution-NonCommercialNoDerivatives 4.0 International (CC BY-NC-ND 4.0) licence. Full details of this licence are available at: https://creativecommons.org/licenses/by-nc-nd/4.0/

\section{LICENCE}

CC BY-NC-ND 4.0

\section{REPOSITORY RECORD}

Sohail, M., Sue Cavill, and Oluwasola O.D. Afolabi. 2019. "Transformative Technologies for Safely Managed Sanitation". figshare. https://hdl.handle.net/2134/23291. 


\title{
Reinvented toilets: transformative technologies for safely managed sanitation
}

\section{Author 1}

Professor M. Sohail , BEng, MSc, PhD (UK), Fellow ASCE (USA); Professor of Sustainable Infrastructure School of Civil and Building Engineering, Loughborough University Loughborough, UK

\section{Author 2}

Sue Cavill, BSc (Hons.), MSc, PhD (UK); WEDC Associate

\section{Author 3}

Oluwasola O.D. Afolabi, BEng (Hons.), MSc, PhD (UK); Research Associate School of Civil and Building Engineering, Loughborough University, Loughborough, UK

\section{Full contact details of corresponding author}

\section{E-mail address: M.Sohail@lboro.ac.uk}

Address: $\quad$ School of Civil and Building Engineering, Loughborough University, Loughborough,

$$
\text { LE11 3TU, UK }
$$

\begin{abstract}
2.4 billion people lack access to safe sanitation. The potential of new technologies to address this need in lowand middle-income countries has been under-addressed in research, programming and policy. Despite global efforts to improve access to sanitation, there has been insufficient attention to the role of transformative technologies to respond to these needs. There is an urgent need for innovation, in particular for safe faecal sludge management, not least to secure its benefits for health and wellbeing. This paper provides a short review of evolving technologies that are being developed to treat human faecal sludge together with insights into the use and implications of such technologies. A case study is presented on the toilet Loughborough University has designed, which uses hydrothermal carbonisation processes. The paper concludes with essential considerations for guiding national policy makers, the private sector, sanitation programme implementers and donors focused on improving access to safely managed sanitation.
\end{abstract}

\section{Keywords (chosen from ICE Publishing list)}

International, sanitation, public health, innovation, technology, waste management

\subsection{Background}

Donors and development agencies are increasingly focusing on sanitation in their efforts to eradicate poverty. Supporting adequate, private, clean, and safe toilets is central to this. Sanitation is defined as the provision and access to facilities and services for safe management of human faecal sludge (HFS), which entails collection, containment, transportation, treatment and final disposal. Despite a growing body of literature and monitoring data on the sanitation challenges facing those in low- and middle-income countries (LMIC), evidence and experience on the potential of technologies to address this need remains limited. The lack of sanitation is a rights, equity, wellbeing, and health concern; this paper examines the potential of innovation in the field of HFS in response to these unmet needs. 
Globally, an estimated 2.4 billion people lack access to safe forms of sanitation of which 946 million people practice open defecation (UNICEF/WHO, 2015). About 89 per cent of these people live in Asia and Sub-Saharan Africa (WHO/UNICEF, 2015), with marked inequities between rural and urban areas as well as between the rich and poor. The health, economic and dignity-related consequences of poor sanitation are severe and pervasive. Analyses of household access to sanitation indicates that there exist economic benefits from less time being sick, less money spent on medications and less time missing school or work. It is estimated that lack of safe sanitation costs 18 countries in sub-Saharan Africa 1 - 2.5 per cent of their GDP annually (WSP, 2012). If the current trajectory continues, universal access to sanitation will not be achieved by 2030, meaning that another generation will miss the benefits that access to safe sanitation can bring.

\subsection{The case for technological innovation}

Global efforts to improve access to sanitation have focused on 'use of an improved sanitation facility' focused on hygienic separation of excreta from human contact. Until recently the complexity of faecal waste management has not been adequately reflected in definitions of safe sanitation. Consultations on the ambitions of the Sustainable Development Goals (SDGs) established consensus on the need to address safe management of faecal waste along safe facilities. Global targets aim to achieve access to adequate and equitable sanitation and hygiene for all and end open defecation by 2030 , as well as to halving the proportion of untreated wastewater by 2030. 'Safely managed sanitation services' comprise three main elements: (1) a basic sanitation facility (such as a pit latrine or pour flush latrine), which is (2) not shared outside the household, and (3) where excreta are safely disposed in situ or transported and treated off-site.

The Joint Monitoring Programme (JMP) 'sanitation ladder' suggests that as people solve immediate sanitation needs they will gradually improve their type of sanitation facility. It is envisaged that this will eventually result in off-site solutions, a flush toilet linked to a networked, sewerage system that facilitates its transportation to centralized wastewater treatment plants. However, the likelihood that the flush toilet will provide a solution for all in LMIC is undermined by the global challenge of water security together with the sustainability of capital- and energy-intensive sewerage networks and wastewater treatment plants.

On-site sanitation (such as pit latrines or septic tanks) is likely to continue to be the most widely utilized and low-cost option in urban, peri-urban areas and small towns particularly in the context of rapid increases in population and urbanization. Conventional on-site sanitation technologies contain HFS but require emptying; in densely populated urban areas relocating full pits is not an option. Pit emptying is often done by manual labourers and/or manually supported technology (such as the Gulper, Vacutug, or the MAPET (Manual Pitlatrine Emptying Technology) or else by emptying technology mounted on a vehicle such as Vacutug, Chinese Tiller ( 2 wheeled tractor), or motor-trikes with bins for carting the waste. HFS (along with the other solid waste that is put into the pits) can be disposed of by transportation to a sewage treatment plant, or disposing into a main sewer, composting or burying at a landfill site, sludge disposal site or sludge drying ponds. Challenges associated with collection and treatment of HFS - aside from the health risks associated with handling includes cost of pit emptying, space requirements (for containment and treatment for example) and difficulty in emptying/access to pits in highly congested areas or where road networks are poor. Data on disposal or treatment of excreta are not yet available for all countries but indications are that these conventional approaches are labour intensive and ineffective: in most cases they have failed to address basic health and 
environmental needs (Eckoff \& Wood, 2011; EAWAG/SANDEC, 2008). In many cases, uncontrolled and indiscriminate disposal of HFS into drains, canals and open places occur or else the contents of the pit are sluiced out in the rainy season or otherwise discharged into the environment without any form of treatment.

It is essential to curtail unsanitary pit latrines and unsafe septic tanks emptying practices as well as to displace or hinder the use of more traditional technologies for pit emptying. To make a swifter (and more significant) contribution to improving safely managed sanitation, the introduction of new 'disruptive' technologies for lowcost, hygienic and sustainable faecal sludge management services is imperative.

\subsection{Review of transformative technological options}

Accelerating the development of transformative technologies in the processing and treatment of HFS is vital: provision and access to sustainable and scalable technologies will play a crucial role in achieving the SDG of universal access to safe improved sanitation (although it is recognised that this alone will not be sufficient). Transformative technology for processing human faecal waste must primarily:

- destroy pathogens and produce stabilised non-biologically active products,

- $\quad$ eradicate odour to acceptable levels, and

- recover value-added resources.

Evolving transformative technologies can be assessed in the following four general categories: thermal, biochemical, mechanical and thermochemical processes. Illustrated with examples, these categories are discussed within the context of a global competitive programme, supported by Bill \& Melinda Gates Foundation, to 'Reinvent the Toilet'. The challenge is to make self-sustainable decentralised toilets that are safe (collect and process HFS and discharge sterilized products); recover valuable resources (energy, fertilizer, water, minerals); yet affordable (less than $\$ 0.05 /$ person/day), desirable and acceptable.

\subsection{Thermal processes}

Thermal processes involve heating waste to high temperatures (650 to $1100^{\circ} \mathrm{C}$ ) in the presence of air (oxygen) to ensure the complete destruction of its components. Examples include incineration or co-incineration systems. They usually require feeding dried raw waste into a refractory chamber, where combustion occurs to generate $\mathrm{CO}_{2}$, water, ash, and char. Energy recovery, in the form of heat/electricity generation, is the main end use for thermal processes (Guibelin, 2004). Thermal processes are capital-intensive due to the nature of the technology (high-temperature reactors are expensive) and the energy required for dewatering and drying waste before incineration (Luts et al, 2000). In addition, gaseous pollutants such as dioxins and greenhouse gases have led to relatively low public acceptance of the technology (Luts, et al, 2004). Examples of technology-based sanitation facility that have adopted this process are summarised in Table 1.

Table 1: Examples of sanitation facility based on thermal process (adapted from Bill \& Melinda Gates Foundation (March 2014) Reinvent the Toilet India Fair Program)

\subsection{Biochemical processes}

Biochemical processes rely on anaerobic or photosynthetic microorganisms that decompose waste to generate liquid (alcohols) and gaseous fuels, while the slurry residue can be used to condition land/soil (Cantrell et al, 2008). Anaerobic digestion represents a key process in this class of technology, which has been widely 
explored for the generation of biogas from livestock manure, sewage sludge and municipal wastes. Biochemical processes are widely employed in centralised sewage/wastewater treatment plants as well. Biochemical processes require days to weeks or even months to completion (Cantrell et al, 2008). Other drawbacks include: malodour, greenhouse gas emissions, the need to accommodate large facilities and the inevitable reliance on microbial culture or feed that is susceptible to toxic pollutants in the feedstock. Also, biochemical processes are not guaranteed to deliver pathogen destruction. For example, the highest temperature range of anaerobic digestion, i.e. the thermophilic range, is $45-60^{\circ} \mathrm{C}$ - too low theoretically for pathogenic inactivation. See Table 2 for examples of toilets based on this processes.

Table 2: Examples of sanitation facility based on biochemical processes (adapted from Bill \& Melinda Gates Foundation (March 2014) Reinvent the Toilet India Fair Program)

\subsection{Mechanical processes}

Freeze/thawing and membrane technologies are principal examples under this category. These methods can be used as a stand-alone treatment process or as a complementary process, normally with anaerobic digestion. Membrane technologies can recover valuable products such as proteins and enzymes from waste. Ultra-sonication has been used to recover certain proteins from primary sewage sludge (Hwang et al, 2008). Enzymes such as dehydrogenase, catalase and protease recovered via membrane filtration or ultra-sonication may be used in enzymatic hydrolysis processes to recover biofuels, e.g. bioethanol, biodiesel (Demibras et al, 2011), or to enhance the biodegradation and digestibility of biowaste, e.g. sludge for biogas production especially with respect to anaerobic digestion (Nabarlatz et al, 2010). However, this technology is susceptible to fouling/clogging of membranes, requires high-energy inputs and is capital intensive. Additionally, the potential for pathogen inactivation has not been demonstrated. The freeze-thawing low temperature storage process involves short (hours) to mid-term (up to 30 days) storage of biowaste such as sewage sludge at temperatures between $-25^{\circ} \mathrm{C}$ and $-7^{\circ} \mathrm{C}$, with the aim of reducing pathogenic load, notably of $E$. coli (Gao et al, 2006). The process also requires high-energy input due to the inevitable low temperature requirement for freezing. Apart from the inability to destroy pathogens, this process has yet to recover any valuable end product. The method has recorded little success in terms of pathogen deactivation. Examples are summarised in Table 3.

Table 3: Examples of sanitation facility based on mechanical processes (adapted from Bill \& Melinda Gates Foundation (March 2014) Reinvent the Toilet India Fair Program)

\subsection{Thermochemical processes}

Thermochemical processes such as flash carbonization, dry pyrolysis, gasification and super critical water oxidation have been studied for solid, liquid and gaseous fuel recovery from biowastes including chicken litters, swine manure and sewage sludge (Cantrell et al, 2007, Stolarek and Ledakowicz 2001). Depending on the thermochemical processes, heat is supplied from $180^{\circ} \mathrm{C}$, or higher - up to $1000^{\circ} \mathrm{C}$, usually in the absence of oxygen. The high temperatures decompose and reform organic components in biowaste to form useful components such syngas, hydrocarbon gases such as methane $\left(\mathrm{CH}_{4}\right)$, ethane $\left(\mathrm{C}_{2} \mathrm{H}_{6}\right)$, oxygenated bio-oil and a solid char residue which have different end-use potentials (Bridgewater and Peacocke, 2000).

As well as the complex engineering required for thermochemical processing, there are other challenges. For most processes under this category, dried feedstock is required as a starting material, introducing additional 
energy requirements and costs. This is especially true when considering HFS, which can contain up to $95 \%$ moisture. The emission of greenhouse gases (although low) and dioxins has also been associated with pyrolysis processes (Rulkens, 2008). Thermochemical processes can ensure pathogen destruction, involve short processing times (in the region of minutes), require a small footprint and can achieve mass reduction of biowaste by up to $40 \%$. They can also promote recovery of other valuable resources such as coagulants and phosphates, as well as fuel resources (Cantrell, 2007). Table 4 provides a summary of the sanitation facilities being developed based on these processes.

Table 4: Examples of sanitation facility based on thermochemical processes (adapted from Bill \& Melinda Gates Foundation (March 2014) Reinvent the Toilet India Fair Program)

Case study: The HTC (hydrothermal carbonization) Toilet, Loughborough University

With funding from the Bill \& Melinda Gates Foundation, Loughborough University has designed a toilet that uses a thermochemical process (hydrothermal carbonization) to convert human waste into biological charcoal (biochar) under temperatures of $180^{\circ} \mathrm{C}$ and pressure conditions in the absence of oxygen. This process completely eradicates the odour associated with human waste to generate pathogen-free end products including biochar (useful as fuel or soil additive), nutrients for fertilizer (e.g. ammonia liquor concentrate) and water for potential reuse. The toilet can handle both urine and excreta as well as accommodate sanitary products and other organic waste including food waste. The toilet is designed to minimize flushing volume, approximately $0.5 \mathrm{I}$ per flush (although additional water may be needed for toilet cleaning purposes).

Table 5: Reinvented Loughborough HTC Toilet

Based on this categorization, Table 6 provides a review of the transformative technologies that have been applied to sanitation whilst also recovering value-added end products as well as to generate heat or electricity. 
Table 6 Assessment of transformative sanitation technologies 


\subsection{The enabling environment for transformative sanitation technologies}

Much of the innovation in transformative sanitation technologies described previously is donorbacked and takes place in academic research groups. At present there is relatively little contextspecific information available on their application in LMIC and use in households as well as institutions (such as schools and health facilities) including user-acceptability and willingness to pay as well as factors associated with operation and maintenance. Implementing the mechanisms to establish long-term stability for new technologies in LMIC is an important and significant challenge. To have impact the development of new technologies must go hand in hand with the necessary policies, institutions and programmes that will facilitate access to the best of proven, appropriate and environmentally sound technologies.

As well as being alert to innovative technologies, national policy and programme decision makers must predict the innovations or new developments that have the potential to be game-changers, expand small-scale pilots and invest for long-term, transformational change in sanitation chains. Ministries of Health and sanitation-related ministries have a role to play, particularly in establishing regulatory frameworks and enforcement related to the treatment and disposal of faecal sludge. An enabling environment is required for private companies to develop manufacturing capacity, invest in domestic technological capabilities and use markets to distribute the technologies and services for the rapid adoption. NGOs, social entrepreneurs and the private sector have a role in creating demand for affordable, acceptable and safely managed options for sanitation at the household and community level and specifically to scale-up the use of new technologies.

Policy and programme considerations for the use of sanitation technologies (see Fig. 1) include the economics (purchase costs, maintenance costs and financial barriers that prevent sanitation businesses from making the most of research and innovation), environmental factors (size, noise, compatibility within the dwelling, greenhouse gas emissions, air pollution) and also socio-cultural factors (including customs for open defecation and expectations for use of sanitation facilities) (Tyagi and Lo, 2013). These factors are intertwined and must be considered at every stage of sanitation technology development along the sanitation chain from R\&D stage to prototype design/testing and production of the final market product.

Fig 1: Policy and programme considerations for sanitation technology

\subsection{Conclusion}

Increasing access to improved sanitation that safely manages HFS is beneficial to health, wellbeing and economic development. It also contributes to human dignity and the attainment of human rights. The scale of the challenge in reaching universal access to safely managed sanitation by 2030 is such that it requires increased investment in technological innovation. This paper describes a number of transformative technologies that could effectively reinvent the toilet by providing a safer, reliable, affordable and more environmentally sustainable service to deal with faecal sludge. New technologies must go hand in hand with action at policy and programme levels including policy incentives, countrylevel standards and regulations, demand creation, manufacturing capacity, and market expansion. Thus, there is a critical role for the private sector, national governments and international bodies to address the critically neglected issue of safely managed sanitation and realise the potential of transformative sanitation technologies in fostering sustainable development.

\section{Acknowledgement}

The authors wish to thank the Bill \& Melinda Gates Foundation for its funding to Loughborough University in particular Dr Doulaye Kone and Dr Carl Hensman. The views expressed in this paper are those of the authors. 


\section{Reference}

- Bill \& Melinda Gates Foundation (March 2014) Reinvent the Toilet India Fair Program

- Blackett, I., Hawkins, P., Heymans, C. (2014). The missing link in sanitation service delivery. A review of fecal sludge management in 12 Cities. Water and Sanitation Program (WSP), International Bank for Reconstruction and Development/The World Bank

- Cantrell, K.B., Ducey, T., Ro, K.S, Hunt, P.G., 2008. Livestock waste to bioenergy generation opportunities. Bioresource Technology, 99, 7941-7953.

- EAWAG/SANDEC, 2008. Faecal Sludge Management (FSM). SANDEC: Department of Water and Sanitation in Developing Countries Training Tool 1.0-Module 5.

- Eckhoff, P. and Wood, L., 2011. Reinvent the toilet challenge: Concept and background For the Bill and Melinda Gates Foundation.

- Gao, W., Smith, D.W., Lib., Y, 2006. Natural freezing as a wastewater treatment method: inactivation capacity. Water Research, 40, 2321-2326.

- Guibelin, E., 2004. Sludge Thermal oxidation processes: Mineral recycling, energy impact and greenhouse effects of gases releases. Water Science and Technology, 29, 209-216.

- Hwang, J., Zhang, L., Seo, S., Lee, Y.W., Jhang D., 2008. Protein recovery from excess its use as animal feed. Bioresource Technology, 99, 8949-8954.

- Luts, D., Devoldere, K., Laetham B., Bartholomueeusen, W., Ockier, P., 2000. Co- incineration of dried sewage sludge in coal-fired power plants: a case study. Water Science and Technology, 42, 259-268.

- Nabarlatz, D., Vondrysova, J., Janicek, P., Stuber, F, Font, J., Firtuny, A, 2010. Hydrolytic enzymes in activated slduge: extraction of protease and lipase by stirring and ultra- son ication. Ultrasonic Sonochemistry, 17, 923-931.

- Rulkens, W. 2008. Sewage Sludge as a Biomass Resource for the Production of Energy: Overview and Assessment of the Various Options. Energy \& Fuels, 22, 9-15.

- Tyagi, V.K., Lo, S.-H., 2013. Sludge: A waste or renewable source for energy and resources recovery? Renewable and Sustainable Energy Review, 25, 708-728.

- UN HABITAT 2014. Sustainable Development Goals Goal 6: Ensure access to water and sanitation for all. Available at: http://www.un.org/sustainabledevelopment/water-and-sanitation/

- Water and Sanitation Programme (WSP) 2012: Africa: Economics of Sanitation Initiative. Available at https://www.wsp.org/content/africa-economic-impacts-sanitation

- WHO and UNICEF 2015: Progress on Sanitation and Drinking Water - 2015 update and MDG assessment 


\begin{tabular}{|c|c|}
\hline Organisation & Description \\
\hline $\begin{array}{l}\text { University of Colorado Boulder } \\
\text { (Sol-Char System) }\end{array}$ & $\begin{array}{l}\text { Uses concentrated solar energy (parabolic dishes) delivered to a } \\
\text { reaction chamber via fibre optic bundles. Faecal material is } \\
\text { transformed into char, which can be used as a soil amendment } \\
\text { or as solid fuel, while urine is thermally treated to produce } \\
\text { nitrogen-rich fertilizer. }\end{array}$ \\
\hline $\begin{array}{l}\text { California Institute of Technology } \\
\text { (PV-Powered Domestic Toilet) }\end{array}$ & $\begin{array}{l}\text { Uses the solar energy to power an electrochemical reactor that } \\
\text { breaks down water and human waste into fertilizer and } \\
\text { hydrogen, which can be used in hydrogen fuel cells as energy. } \\
\text { The treated water can then be reused to flush the toilet or for } \\
\text { irrigation. }\end{array}$ \\
\hline Omni-processor Janicki Industries & $\begin{array}{l}\text { Omni-Processor is a combined heat and power plant that uses } \\
\text { faecal sludge as the fuel source for electricity generation. The } \\
\text { heat from combustion within a fluidized sand bed is utilized to } \\
\text { generate high-pressure steam that is expanded in a reciprocating } \\
\text { piston steam engine connected to a generator, producing } \\
\text { electricity. The exhaust from this engine (process heat) is used to } \\
\text { dry the incoming faecal sludge. }\end{array}$ \\
\hline
\end{tabular}

Table 1: Examples of sanitation facility based on thermal process (adapted from Bill \& Melinda Gates Foundation (March 2014) Reinvent the Toilet India Fair Program)

\begin{tabular}{|l|l|}
\hline Organisation & Description \\
\hline $\begin{array}{l}\text { Duke University } \\
\text { (Anaerobic Digestion } \\
\text { Pasteurization System) }\end{array}$ & $\begin{array}{l}\text { Human waste is treated in an anaerobic digester. This is followed by heat } \\
\text { sterilization of the treated effluent in a novel heater/heat recovery system } \\
\text { powered by the biogas produced by the anaerobic digester. Some of the } \\
\text { biogas is then combusted in a special heater-heat exchanger system, which } \\
\text { pasteurizes the effluent from the digester, thereby providing a pathogen- } \\
\text { free effluent, safe to be discharged. }\end{array}$ \\
\hline $\begin{array}{l}\text { Stone India Limited } \\
\text { (Aerobic Biological }\end{array}$ & $\begin{array}{l}\text { The system decomposes the waste and converts it into water by the } \\
\text { bacterial digestion. This resultant water then passes on to a disinfection } \\
\text { Toilets) }\end{array}$ \\
\hline
\end{tabular}

Table 2: Examples of sanitation facility based on biochemical processes (adapted from Bill \& Melinda Gates Foundation (March 2014) Reinvent the Toilet India Fair Program)

Table 3

\begin{tabular}{|l|l|}
\hline Organisation & Description \\
\hline $\begin{array}{l}\text { Cranfield University } \\
\text { (Nano Membrane Toilet) }\end{array}$ & $\begin{array}{l}\text { Innovative nano-membrane and advanced water treatment technologies reduce the } \\
\text { water content of the sludge through membranes that allow extraction of water as a } \\
\text { vapour, using a mechanism powered by the user. The resulting sludge moves } \\
\text { downwards under gravity and is encapsulated in briquette form, with the potential } \\
\text { for reuse in combusting or applying to land as a fertiliser. }\end{array}$ \\
\hline EAWAG & $\begin{array}{l}\text { Undiluted urine, faeces, and flush and wash water are collected separately. The } \\
\text { water is treated in a self-cleaning ultrafiltration unit and reused on-site. Resources } \\
\text { from urine and faeces are also recovered separately }\end{array}$ \\
\hline $\begin{array}{l}\text { Asian Institute of } \\
\text { Technology } \\
\text { (Hydrocyclone Toilet) }\end{array}$ & $\begin{array}{l}\text { Separated solids are treated primarily by heat application produced by solar energy } \\
\text { and separated liquid disinfected using electrochemical technology }\end{array}$ \\
\hline
\end{tabular}

Table 3: Examples of sanitation facility based on mechanical processes (adapted from Bill \& Melinda Gates Foundation (March 2014) Reinvent the Toilet India Fair Program) 


\begin{tabular}{|l|l|}
\hline Organisation & Description \\
\hline $\begin{array}{l}\text { National } \\
\text { University of }\end{array}$ & $\begin{array}{l}\text { The system: transforms faeces into biochar through pyrolysis; recovers urine } \\
\text { and cleansing water into clean water by evaporation, condensation and } \\
\text { sand/zeolite filtration; produces fertilizers from concentrated urine; and } \\
\text { provides odour control by a ventilation fan powered by a microbial fuel cell. }\end{array}$ \\
\hline $\begin{array}{l}\text { Duke University } \\
\text { and the University } \\
\text { of Missouri }\end{array}$ & $\begin{array}{l}\text { Faeces and urine are compressed, heated and mixed with air and supercritical } \\
\text { water (recycled internally in the process). The high pressure and temperature } \\
\text { promote rapid conversion of the organics in the waste. }\end{array}$ \\
\hline $\begin{array}{l}\text { Delft University of } \\
\text { Technology }\end{array}$ & $\begin{array}{l}\text { A Microwave Plasma Gasification process is used to generate electricity out of } \\
\text { dried faeces that is fed into a gasifier. Human waste is converted into a } \\
\text { disinfected ash, with the possibility of recovering nutrients such as phosphate, a } \\
\text { valuable fertilizer. }\end{array}$ \\
\hline
\end{tabular}

Table 4: Examples of sanitation facility based on thermochemical processes (adapted from Bill \& Melinda Gates Foundation (March 2014) Reinvent the Toilet India Fair Program)

\begin{tabular}{|c|l|l|}
\hline \multicolumn{2}{|c|}{ Parameters } & \multicolumn{1}{|c|}{ Features } \\
\hline Costs & Capital ( Target) & $\$ 600$ \\
\cline { 2 - 3 } & Daily operating cost (Target) & $\sim \$ 0.05 /$ user/day \\
\hline Technical & Pathogen treatment & Total pathogen removal \\
\cline { 2 - 3 } & Odour management & Eradication of foul odour associated with raw HFS \\
\cline { 2 - 3 } & Completed operational duration & $\begin{array}{l}\sim 4400 \text { hours of operation including in China and } \\
\text { Senegal }\end{array}$ \\
\cline { 2 - 3 } & $\begin{array}{l}\text { Water requirement ) for the } \\
\text { particular unit being tested but } \\
\text { can vary) }\end{array}$ & $\sim 0.5 \mathrm{~L}$ per flush \\
\cline { 2 - 3 } & Electricity requirement & AC and DC \\
\cline { 2 - 3 } & $\begin{array}{l}\text { No of users (for the unit being } \\
\text { tested) }\end{array}$ & $6-40$ users \\
\cline { 2 - 3 } & $\begin{array}{l}\text { Need for biological process/off- } \\
\text { site waste processing }\end{array}$ & None \\
\cline { 2 - 3 } & System life expectancy & $5-20$ years \\
\hline
\end{tabular}

Table 5: Reinvented Loughborough HTC Toilet

Table 6 Assessment of transformative sanitation technologies

\begin{tabular}{|c|c|c|c|c|c|c|c|c|}
\hline Technologies & Thermal & \multicolumn{5}{|c|}{ Thermochemical } & \multicolumn{2}{|c|}{ Biochemical } \\
\hline $\begin{array}{l}\text { Example of } \\
\text { Processes }\end{array}$ & $\begin{array}{l}\text { Incineration/ } \\
\text { Co-incineration }\end{array}$ & Pyrolysis & Gasification & $\begin{array}{c}\text { Flash } \\
\text { Carbonization }\end{array}$ & $\begin{array}{c}\text { Super-critical } \\
\text { water oxidation }\end{array}$ & $\begin{array}{l}\text { Hydrothermal } \\
\text { Carbonization }\end{array}$ & $\begin{array}{l}\text { Anaerobic } \\
\text { digestion }\end{array}$ & $\begin{array}{r}\text { Aerobic an } \\
\text { microbial/ er } \\
\text { proces }\end{array}$ \\
\hline $\begin{array}{l}\text { Required Form of } \\
\text { waste prior } \\
\text { processing }\end{array}$ & \multicolumn{4}{|c|}{ Dry } & $\begin{array}{l}\text { Wet, but must be } \\
\text { pre-thickened }\end{array}$ & $\begin{array}{l}\text { Wet and dry (but } \\
\text { must be } \\
\text { immersed in } \\
\text { water) }\end{array}$ & & \\
\hline $\begin{array}{l}\text { Potential end } \\
\text { products }\end{array}$ & $\begin{array}{l}\text { Heat, } \mathrm{CO} 2, \\
\text { ash }\end{array}$ & $\begin{array}{l}\text { Bio-oil, ash, } \\
\text { char, fuel } \\
\text { gas, }\end{array}$ & $\begin{array}{l}\text { Syngas, fuel } \\
\text { gas }\end{array}$ & $\begin{array}{l}\text { Heat, char, fuel } \\
\text { gas }\end{array}$ & $\begin{array}{l}\text { Phosphorus, } \\
\text { energy, coagulant }\end{array}$ & $\begin{array}{l}\text { Char, nutrient- } \\
\text { rich liquor, } \\
\text { energy }\end{array}$ & $\begin{array}{l}\text { Biogas, fuel } \\
\text { gas }\end{array}$ & $\begin{array}{r}\text { Compost, } \mathrm{H} 2 \\
\text { plasti } \\
\text { methanol/ } /\end{array}$ \\
\hline End uses & $\begin{array}{l}\text { Process heat, } \\
\text { power } \\
\text { generation, } \\
\text { building or } \\
\text { construction } \\
\text { materials }\end{array}$ & $\begin{array}{l}\text { Process } \\
\text { heat, fuel } \\
\text { resource, } \\
\text { recovery of } \\
\text { heavy } \\
\text { metals }\end{array}$ & $\begin{array}{l}\text { Process heat, } \\
\text { Power } \\
\text { generation, } \\
\text { alternative } \\
\text { natural gas }\end{array}$ & $\begin{array}{l}\text { Process heat, } \\
\text { power } \\
\text { generation }\end{array}$ & $\begin{array}{l}\text { Potential for } \\
\text { building and } \\
\text { construction } \\
\text { materials }\end{array}$ & $\begin{array}{l}\text { Solid char fuel, } \\
\text { biogas } \\
\text { generation from } \\
\text { liquor, liquor as } \\
\text { commercial } \\
\text { fertilizer, carbon } \\
\text { sink }\end{array}$ & $\begin{array}{l}\text { For heat and } \\
\text { power } \\
\text { generation }\end{array}$ & $\begin{array}{r}\text { Use as fert } \\
\text { Power gen } \\
\text { Fuel ce }\end{array}$ \\
\hline $\begin{array}{l}\text { Costs and energy } \\
\text { requirements }\end{array}$ & \multicolumn{5}{|c|}{$\begin{array}{l}\text { High-energy inputs and } \\
\mathrm{h} \text { (initial and running) costs }\end{array}$} & Low-moderate & \multicolumn{2}{|c|}{ Moderate } \\
\hline
\end{tabular}




\begin{tabular}{|c|c|c|c|c|c|}
\hline $\begin{array}{c}\text { Technological } \\
\text { maturity/ } \\
\text { development stage }\end{array}$ & $\begin{array}{l}\text { Well established } \\
\text { and applied at } \\
\text { full scale }\end{array}$ & $\begin{array}{l}\text { Successful at pilot scales and potentially nearing } \\
\text { full scale }\end{array}$ & $\begin{array}{l}\text { Laboratory stage. } \\
\text { Challenges with } \\
\text { pilot scaling }\end{array}$ & $\begin{array}{c}\text { Still at laboratory } \\
\text { and } \\
\text { experimental } \\
\text { pilot scale }\end{array}$ & $\begin{array}{l}\text { Well established and applie } \\
\text { scale }\end{array}$ \\
\hline $\begin{array}{l}\text { Socio-environmental } \\
\text { factors, e.g. public } \\
\text { health, land } \\
\text { requirements, GHG } \\
\text { emissions }\end{array}$ & $\begin{array}{l}\text { Poor public } \\
\text { acceptance. } \\
\text { Greenhouse } \\
\text { gases } \\
\text { emissions/air } \\
\text { pollution. } \\
\text { Moderate land } \\
\text { requirement }\end{array}$ & $\begin{array}{l}\text { Moderate to large land requirement depending } \\
\text { on scaling } \\
\text { Potential greenhouse gases emissions } \\
\text { Minimal to moderate chemical use }\end{array}$ & \multicolumn{2}{|c|}{$\begin{array}{l}\text { Effective odour management } \\
\text { Complete reduction in greenhouse } \\
\text { gases emissions } \\
\text { Very small footprint due to reduced } \\
\text { reactor sizes }\end{array}$} & $\begin{array}{c}\text { Odour nuisance } \\
\text { Emission of greenhouse } q \\
\text { Phosphates and ammonia } \\
\text { process } \\
\text { Large footprint requirem }\end{array}$ \\
\hline $\begin{array}{l}\text { Potential for } \\
\text { decentralized } \\
\text { sanitation } \\
\text { technology }\end{array}$ & \multicolumn{2}{|c|}{$\begin{array}{l}\text { May not suitable for decentralisation at household level due to nature } \\
\text { of process } \\
\text { May involves high temperatures and pressures and heavy machinery }\end{array}$} & $\begin{array}{l}\text { Very complex and } \\
\text { involves high } \\
\text { temperature } \\
\text { ranges. Can't } \\
\text { handle } \\
\text { heterogeneous } \\
\text { feed }\end{array}$ & $\begin{array}{l}\text { Can be } \\
\text { decentralized as } \\
\text { stand-alone. } \\
\text { Minimal } \\
\text { temperature } \\
\text { regimes }\end{array}$ & $\begin{array}{l}\text { Cannot be decentralized to ho } \\
\text { level } \\
\text { Microbial feed requirement } \\
\text { impractical }\end{array}$ \\
\hline
\end{tabular}

Figure 1

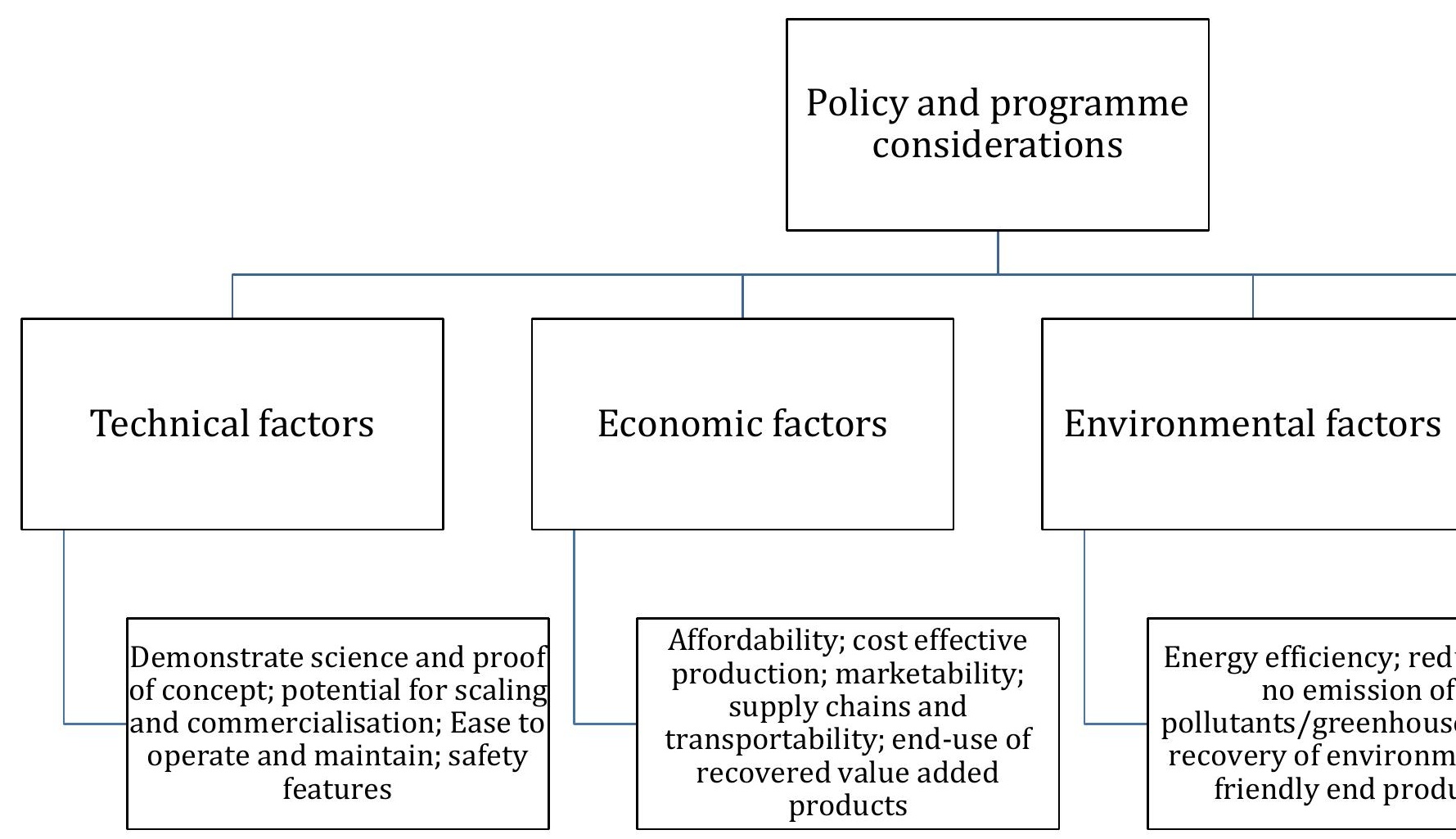

